\title{
KORELASI KOMPETENSI PEDAGOGIK GURU DENGAN PELAKSANAAN PEMBELAJARAN BAHASA JAWA TINGKAT SMP
}

\author{
Seto Setiawan ${ }^{1}$ dan Laksmi Dewi ${ }^{2}$ \\ ${ }^{1}$ Pusat Data dan Statistik Pendidikan dan Kebudayaan, Kemendikbud \\ dan ${ }^{2}$ Universitas Pendidikan Indonesia \\ e-mail: seto.setiawan@kemdikbud.go.id
}

\begin{abstract}
Abstrak
Penelitian yang dilakukan ini bertujuan untuk melihat korelasi antara kompetensi pedagogik guru dengan pelaksanaan pembelajaran bahasa Jawa di Daerah Istimewa Yogyakarta. Sedangkan tujuan khusus dari penelitian ini adalah melihat korelasi antara pemahaman wawasan atau landasan kependidikan dan pemahaman terhadap peserta didik dengan pelaksanaan pembelajaran bahasa Jawa. Metode penelitian yang digunakan adalah deskriptif kuantitatif dengan purposive sampling sebagai teknik pemilihan sampel penelitian. Sekolah yang dipilih sebagai sampel penelitian adalah sekolah yang sudah menerapkan kurikulum 2013 dari kelas 7 hingga kelas 9. Berdasarkan hal tersebut, diperoleh dua puluh sembilan (29) sekolah sampel di Daerah Istimewa Yogyakarta. Dari dua puluh sembilan sekolah sampel tersebut dipilih tiga puluh guru muatan lokal bahasa Jawa sebagai responden penelitian. Pengumpulan data dilakukan menggunakan kuesioner tertutup berdasarkan skala Likert. Sebelum digunakan untuk mengumpulkan data yang dibutuhkan dalam penelitian, dilakukan uji validasi instrumen oleh ahli. Data yang terkumpul dianalisa dengan menggunakan metode regresi linier untuk melihat korelasi dari variabel-variabel penelitian. Hasil yang diharapkan dari penelitian ini adalah adanya korelasi yang positif dan signifikan antara pemahaman wawasan atau landasan kependidikan dan pemahaman terhadap peserta didik dengan pelaksanaan pembelajaran bahasa Jawa. Rekomendasi dari penelitian adalah guru harus meningkatkan kemampuan pedagogik seperti: pemahaman wawasan atau landasan kependidikan dan pemahaman peserta didik karena memiliki korelasi dengan pelaksanaan pembelajaran bahasa Jawa.
\end{abstract}

Kata Kunci : korelasi, kompetensi pedagogik, pelaksanaan penbelajaran, bahasa Jawa, regresi linier

\section{CORRELATION OF TEACHER PEDAGOGICAL COMPETENCY WITH THE IMPLEMENTATION OF JAVA LANGUAGE LEARNING LEVEL SMP}

\begin{abstract}
This research aims to see the correlation between pedagogic competence of teachers with the implementation of learning Java language in Special Region of Yogyakarta. While the specific purpose of this research is to see the correlation between understanding insights or educational foundations and understanding of learners with the implementation of learning Java language. The research method used is descriptive quantitative with purposive sampling as the technique of selecting research samples. Schools selected as research samples are schools that have implemented the 2013 curriculum from grade 7 to grade 9. Based on this, obtained twenty-nine (29) sample schools in Special Region of Yogyakarta. Of the twenty-nine sample schools were selected thirty teachers of local Javanese content as research respondents. The data were collected using a closed questionnaire based on Likert scale. Before being used to collect the required data in the study, validation of the instrument is performed by the expert. The collected data were analyzed by using linear regression method to see correlation of research variables. The expected result of this research is a positive and significant correlation between understanding insight or educational base and
\end{abstract}


learners' understanding with the implementation of learning Java language. The recommendation of the research is that teachers should improve pedagogical skills such as: understanding of knowledge or educational base and learners' understanding because it has correlation with the implementation of learning Java language.

Keywords: correlation, pedagogic competence, learning implementation, Javanese language, linear regression

\section{PENDAHULUAN}

Bahasa merupakan elemen penting dalam kehidupan manusia karena fungsinya sebagai alat komunikasi dalam berinteraksi dengan sesama manusia. Dengan kata lain, bahasa merupakan kebutuhan primer dalam kehidupan bermasyarakat, berbangsa dan bernegara. Sebagai sarana komunikasi, bahasa mempunyai fungsi utama dalam menyampaikan pesan dari komunikator kepada komunikan baik secara langsung maupun tidak langsung.

Dalam Atlas of the World's Language in Danger of Disappearing disebutkan bahwa Indonesia memiliki lebih dari 640 bahasa daerah (Wurm, 2001). Bahasa daerah yang ada tersebut, 154 diantaranya perlu diperhatikan keberadaannya. Perhatian terhadap bahasa dilakukan oleh pemerintah melalui pemberlakuan mata pelajaran muatan lokal.

Penyelenggaraan pendidikan muatan lokal tidak terpusat sehingga daerah ataupun sekolah dapat mengembangkan sendiri muatan lokal yang diinginkan sesuai dengan kebutuhan. Dengan demikian, penyelenggaraan pendidikan disetiap daerah dapat lebih meningkat relevansinya terhadap keadaan dan kebutuhan daerah yang bersangkutan. Muatan lokal diselenggarakan sejalan dengan peningkatan mutu pendidikan nasional sehingga keberadaannya mendukung dan melengkapi kurikulum nasional.

Pemerintah Daerah Istimewa Yogyakarta dalam praktek pendidikan di daerahnya menyelenggarakan muatan lokal Bahasa Jawa. Kebijakan ini sejalan dengan kebijakan Pemerintah Indonesia di mana muatan lokal menjadi bagian dalam Kurikulum 2013. Kebijakan penyelenggaran muatan lokal bahasa Jawa didorong dengan diterbitkannya Peraturan Gubernur
DIY Nomor 64 Tahun 2013 tentang Mata Pelajaran Bahasa Jawa sebagai Muatan Lokal Wajib di Sekolah/ Madrasah. Penyelenggaraan muatan lokal Bahasa Jawa bertujuan untuk meningkatkan kemampuan intelektual, kematangan emosional dan sosial, memperhalus budi pekerti, dan meningkatkan pengetahuan peserta didik, serta meningkatkan sarana komunikasi antara peserta didik dengan guru.

Guru merasakan bahwa mata pelajaran bahasa Jawa kurang mendapatkan perhatian (Siscahyani, 2011). Ini karena mata pelajaran bahasa Jawa kedudukannya hanya sebagai mata pelajaran muatan lokal dalam kurikulum 2013 jenjang SD, SMP, SMA, dan SMK Dengan kata lain, mata pelajaran bahasa Jawa merupakan mata pelajaran sekunder yang berfungsi sebagai pelengkap kurikulum.

Implementasi muatan lokal bahasa Jawa mengalami berbagai permasalahan (Sudjarwadi, 2006). Permasalahan dalam implementasi muatan lokal bahasa Jawa diantaranya adalah guru kurang memahami dan menguasai materi karena tidak didukung dengan latar belakang pendidikan Bahasa Jawa. Pendapat Sudjarwadi di atas dikuatkan oleh Maryono (2016) yang menyatakan bahwa pengetahuan dan keterampilan guru menjadi faktor penghambat dalam implementasi muatan lokal yang dilakukan di sekolah. Keterampilan yang dimaksud oleh Maryono di atas adalah keterampilan dasar mengajar.

Peran guru muatan lokal dalam proses pembelajaran sangat diperlukan dalam rangka mencapai tujuan kurikulum muatan lokal (Wahyuni, 2014). Guru menjadi ujung tombak dalam melaksanakan pembelajaran kepada peserta didik sehingga menghasilkan tamatan yang mempunyai kompetensi 
yang diharapkan. Dengan kata lain, guru memegang peran penting dalam proses pembelajaran. Keberhasilan pencapaian tujuan pendidikan muatan lokal bahasa Jawa sangat bergantung oleh kemampuan guru dalam mengelola proses pembelajaran.

Suwardi (2005) memberikan pandangan bahwa di Madrasah Aliyah, kompetensi guru muatan lokal bahasa Jawa belum sesuai. Guru yang memiliki kompetensi merupakan faktor penentu keberhasilan pelaksanaan pendidikan (Usman, 2011). Dengan kompetensi yang dimiliki, guru dapat menghantarkan peserta didik untuk mencapai tujuan pendidikan. Sebagian masyarakat menilai bahwa pendidikan di Indonesia kurang berhasil. Ini karena guru kurang mampu melaksanakan pembelajaran secara efektif, bermakna, dan menyenangkan (Arifin, 2016). Kompetensi yang dikuasai guru memberikan pengaruh dalam pencapaian keberhasilan guru dalam mengelola pem-belajaran yang pada akhirnya terlihat pada prestasi belajar siswa (Irsyada, 2013). Kemampuan yang dimiliki guru akan membuat peserta didik mengerti pembe-lajaran yang diikutinya. Oleh karena itu, kompetensi guru perlu mendapatkan perhatian serius.

Kompetensi merupakan refleksi dari perpaduan antara pengetahuan, keterampilan nilai, dan sikap dalam kebiasaan berfikir dan bertindak. Charles (Mulyasa, 2008) menyatakan bahwa kompetensi sebagai perilaku rasional dalam rangka mencapai tujuan sebagaimana kondisi yang diharapkan. Senada dengan pendapat di atas, Spencer dan Spencer (Uno, 2007) mengartikan kompetensi sebagai karakteristik yang menonjol dalam diri seseorang yang terlihat dalam perilaku dan cara berfikir dalam segala kondisi. Sedangkan Undang-Undang Republik Indonesia Nomor 14 Tahun 2005 tentang Guru dan Dosen disebutkan bahwa kompetensi sebagai "seperangkat pengetahuan, keterampilan, dan perilaku yang harus dimiliki, dihayati, dan dikuasai oleh guru atau dosen dalam melaksanakan tugas keprofesionalannya".
Proses pembelajaran yang dilakukan guru perlu didukung dengan penguasaan kompetensi pedagogik yang direfleksikan kedalam keterampilan dasar mengajar. Guru perlu memiliki kompetensi pedagogik guna membentuk kepribadian yang baik bagi peserta didik. Strategi dan penguasaan kompetensi pedagogik guru perlu disusun dalam mencapai tujuan pembelajaran sehingga dalam mencapai tujuan tersebut dapat dilakukan secara optimal (Sanjaya, 2007). Kompetensi pedagogik merupakan satu dari empat kompetensi yang wajib dimiliki seorang guru dalam melaksanakan tugasnya.

Kompetensi pedagogik merupakan "kompetensi pengelolaan pembelajaran" (Anwar, 2004:9). Kompetensi pedagogik menurut Mulyasa (2008) menyangkut perencanaan, pelaksanaan, dan pengendalian sebagai fungsi managerial. Sejalan dengan Anwar, Undang-Undang Republik Indonesia Nomor 14 Tahun 2005 tentang Guru dan Dosen menyebutkan kompetensi pedagogik sebagai kemampuan guru dalam mengelola proses pembelajaran terhadap peserta didik. Kompetensi pedagogik dapat dilihat dari rencana guru dalam program pembelajaran, kemampuan melaksanakan interaksi atau mengelola proses belajar mengajar, dan kemampuan melakukan penilaian. Peraturan Pemerintah Nomor 74 Tahun 2008 tentang Guru Bab II Pasal 3 Ayat (4) menyebutkan bahwa kompetensi pedagogik merupakan "kemampuan guru dalam pengelolaan pembelajaran peserta didik". Kemampuan pedagogik guru sekurang-kurangnya meliputi: pemahaman wawasan atau landasan kependidikan, pemahaman terhadap peserta didik, pengembangan kurikulum atau silabus, perancangan pembelajaran, pelaksanaan pembelajaran yang mendidik dan dialogis, pemanfaatan teknologi pembelajaran, evaluasi hasil belajar, dan pengembangan peserta didik untuk mengaktualisasikan berbagai potensi yang dimilikinya (PP No 74 Tahun 2008; Mulyasa, 2008).

Guru yang tidak menguasai kompetensi pedagogik tidak akan dapat menghantarkan peserta didik dalam 
mencapai tujuan pendidikan. Penguasaan guru terhadap kompetensi pedagogik akan menunjang proses pembelajaran sehingga dapat melaksanakan pembelajaran dengan efektif dan efisien. Dengan demikian, mutu pendidikan juga dapat meningkat.

Melihat permasalahan yang ada dalam implementasi kurikulum muatan lokal bahasa Jawa, peneliti tertarik untuk melakukan penelitian dengan judul "Korelasi Kompetensi Pedagogik Guru dengan Pelaksanaan Pembelajaran Bahasa Jawa Tingkat SMP Di Daerah Istimewa Yogyakarta”.

\section{METODE}

Penelitian dilakukan menggunakan pendekatan deskriptif kuantitatif. Pendekatan deskriptif dipilih karena dapat memotret peristiwa dan kejadian berkaitan dengan kompetensi pedagogik guru dalam pelaksanaan pembelajaran muatan lokal bahasa Jawa kemudian digambarkan sebagaimana adanya. Sebagaimana dinyatakan oleh Sudjana dan Ibrahim (2014) penelitian deskriptif mampu mendeskripsikan suatu gejala, peristiwa, kejadian yang terjadi pada saat ini.

Pemilihan pendekatan kuantitatif dalam penelitian ini karena data yang dihasilkan dalam penelitian berupa angka sehingga dapat menggambarkan korelasi kompetensi pedagogik guru dengan pelaksanaan pembelajaran muatan lokal Bahasa Jawa yang menjadi fokus penelitian. Peneliti menggunakan perhitunganperhitungan angka untuk menganalisis seberapa besar korelasi kompetensi pedagogik guru dengan pelaksanaan pembelajaran muatan lokal bahasa Jawa.

Populasi penelitian adalah guru muatan lokal bahasa Jawa SMP di Daerah Istimewa Yogyakarta. Banyaknya jumlah guru muatan lokal bahasa Jawa di Daerah Istimewa Yogyakarta mendorong peneliti untuk mengambil sampel sebagai responden penelitian. Teknik sampling yang digunakan adalah purposive sampling dimana sekolah yang dijadikan sampel adalah sekolah yang sudah menerapkan kurikulum 2013 dari kelas 7 hingga kelas 9.
Purposive sampling dipilih sebagai metode sampling karena dengan metode ini sampel dapat dipilih berdasarkan pada ciri atau karakteristik dan pertimbangan atas dasar tujuan penelitian (Dantes, 2012; Sudjana dan Ibrahim, 2014; Usman dan Akbar, 1995).

Pemilihan sampel dilakukan atas dasar pertimbangan tertentu yang sesuai dengan tujuan penelitian yang dilakukan, yaitu untuk melihat korelasi kompetensi pedagogik guru dengan pelaksanaan pembelajaran muatan lokal bahasa Jawa di Provinsi Daerah Istimewa Yogyakarta. Responden dalam penelitian ini diambil tiga puluh (30) orang guru muatan lokal bahasa Jawa sebagai sampel penelitian yang berasal dari 29 sekolah penyelenggara kurikulum 2013 sebagaimana terlihat pada Tabel 1.

Tabel 1. Sebaran Responden Penelitian

\begin{tabular}{|c|c|c|c|}
\hline No & Kab./Kota & $\begin{array}{c}\text { Jumlah } \\
\text { Guru }\end{array}$ & Responden \\
\hline \multirow{2}{*}{$\begin{array}{l}1 . \\
2 .\end{array}$} & Kab. Bantul & 85 & 6 \\
\hline & $\begin{array}{l}\text { Kab. Gunung } \\
\text { Kidul }\end{array}$ & 37 & 6 \\
\hline 3. & $\begin{array}{l}\text { Kab. Kulon } \\
\text { Progo }\end{array}$ & 18 & 5 \\
\hline \multirow{3}{*}{$\begin{array}{l}4 . \\
5 .\end{array}$} & Kab. Sleman & 57 & 6 \\
\hline & $\begin{array}{l}\text { Kota } \\
\text { Yogyakarta }\end{array}$ & 31 & 7 \\
\hline & Jumlah & 228 & 30 \\
\hline
\end{tabular}

Instrumen pengumpulan data yang digunakan adalah kuesioner tertutup. Kuesioner dipilih sebagai instrumen pengumpulan data karena sifatnya yang praktis, hemat waktu, hemat tenaga, dan hemat biaya (Sudjana dan Ibrahim, 2014). Selain itu, alternatif jawaban yang disediakan dalam kuesioner dapat ditransformasikan dalam bentuk simbol kuantitatif sehingga menghasilkan data interval. Dengan kata lain, instrumen jenis kuesioner mendukung pendekatan kuantitatif yang dipilih peneliti sebagai metode penelitian.

Analisa data dilakukan menggunakan pendekatan korelasional. Pendekatan korelasional dipilih sehingga peneliti dapat mengetahui hubungan yang signifikan 
antara kompetensi pedagogik guru dengan pelaksanaan pembelajaran muatan lokal bahasa Jawa. Dengan pendekatan korelasional, peneliti akan mampu melakukan analisis hubungan antar variabel penelitian. Pendekatan korelasional dilakukan dengan maksud menganalisis derajat hubungan linier atau korelasi antar variabel (Usman \& Akbar, 1995; Suci, 2015). Dengan kata lain, pendekatan korelasional dipilih untuk melihat hubungan variabel satu dengan yang lain.

Uji validitas dilakukan untuk melihat kelayakan instrumen sehingga dapat digunakan untuk melakukan pengukuran. Validitas instrumen adalah akurasi instrumen terhadap yang diukur walaupun dilakukan berkali-kali dan di mana-mana (Bungin, 2011). Oleh karena itu, instrumen harus memiliki akurasi yang baik sehingga instrumen tersebut dapat meningkatkan bobot kebenaran data yang diinginkan peneliti. Sebuah instrumen dikatakan valid apabila mempunyai validitas tinggi sehingga dapat mengukur apa yang diinginkan. Dengan kata lain, instrumen yang valid dapat menjelaskan data penelitian dengan tepat. Uji validitas dilakukan menggunakan rumus product moment Karl Pearson.

$r_{x y}=\frac{N\left(\sum X Y\right)-\left(\sum X\right)\left(\sum Y\right)}{\sqrt{\left(N\left(\sum X^{2}\right)-\left(\sum X\right)^{2}\right)\left(N\left(\sum Y^{2}\right)-\left(\sum Y\right)^{2}\right)}}$

(Arikunto, 2014; Misbahuddin dan Hasan, 2013)

Instrumen penelitian mempunyai reliabilitas tinggi jika hasil penelitian menunjukkan nilai yang konsisten dalam mengukur yang hendak diukur (Sukardi, 2011). Reliabilitas instrumen diuji dengan internal consistency dengan sekali mengujicobakan instrumen penelitian. Data hasil ujicoba instrumen dianalisis menggunakan teknik Cronbach's Alpha (koefisien alpha). Penggunaan Cronbach's Alpha karena jawaban instrumen bersifat gradasi. Metode pengukuran dikatakan reliabel apabila nilai koefisien reliabilitas $\geq$ 0,6. Cronbach's Alpha dirumuskan sebagai berikut:

$$
R_{i i}=\left[\frac{(k)}{(k-1)}\right]\left[\frac{\left(1-\sum \sigma_{b}^{2}\right)}{\sigma_{t}^{2}}\right]
$$

Pengujian hipotesis dilakukan untuk mencari sumbangan dari variabel bebas terhadap variabel terikat. Pengujian hipotesis dalam penelitian ini dilakukan menggunakan teknik analisis korelasi dengan bantuan software Statistical Package Social Science (SPSS) versi 20 for Windows. Adapun hipotesis dalam penelitian ini adalah:

1. Pemahaman wawasan atau landasan kependidikan berkorelasi secara signifikan dengan pelaksanaan pembelajaran muatan lokal bahasa Jawa;

2. Pemahaman terhadap peserta didik berkorelasi secara signifikan dengan pelaksanaan pembelajaran muatan lokal bahasa Jawa; dan

3. Pemahaman wawasan atau landasan kependidikan, pemahaman terhadap peserta didik, perencanaan pembelajaran, dan evaluasi hasil belajar bersama-sama berkorelasi secara signifikan dengan pelaksanaan pembelajaran muatan lokal bahasa Jawa.

\section{HASIL DAN PEMBAHASAN Hasil}

Sebagaimana judul penelitian, variabel yang diteliti dalam penelitian ini adalah: Pelaksanaan Pembelajaran Muatan Lokal Bahasa Jawa sebagai variabel terikat (dependent/Y) dan Kompetensi Pedagogik Guru sebagai variabel bebas (independent) yang terdiri dari: Pemahaman Wawasan atau Landasan Kependidikan sebagai $\mathrm{X}_{1}$ dan Pemahaman terhadap Peserta Didik sebagai $\mathrm{X}_{2}$.

Pernyataan yang digunakan untuk mengukur variabel penelitian berjumlah enam puluh. Jawaban setiap pernyataan mengggunakan skala Likert dengan gradasi nilai sangat positif (5) sampai sangat negatif (1). Jawaban tersebut berupa kata-kata: Sangat Setuju, Setuju, Tidak Tahu, Tidak Setuju, dan Sangat Tidak Setuju. Jawaban dari pernyataan kuesioner penelitian juga menggunakan kata-kata: Sangat Sering, Sering, Kadang-Kadang, Pernah, dan Tidak 
Pernah. Secara umum, data deskriptif masing-masing variabel dirangkum dalam Tabel 2 berikut.

Tabel 2. Data Deskriptif Masing-masing Variabel

\begin{tabular}{lccc}
\hline \multicolumn{1}{c}{ Deskripsi } & $\mathrm{Y}$ & $\mathrm{X}_{1}$ & $\mathrm{X}_{2}$ \\
\hline Rata-rata & 80,6 & 78,27 & 76,5 \\
Median & 80 & 78 & 76 \\
Modus & 76 & 70 & 72 \\
Standar & 6,377 & 6,253 & 7,094 \\
deviasi & 70 & 70 & 64 \\
Minimum & 95 & 90 & 94 \\
Maksimum & 95 \\
Sumber: Hasil Penelitian (Data Diolah)
\end{tabular}

Sedangkan penyajian menurut masing-masing variabel terlihat sebagai berikut, mulai dari variabel pelaksanaan pembelajaran muatan lokal bahasa Jawa (Y), selanjutnya pemahaman wawasan atau landasan kependidikan $\left(\mathrm{X}_{1}\right)$, dan pemahaman terhadap peserta didik $\left(\mathrm{X}_{2}\right)$.

1. Variabel Pelaksanaan Pembelajaran Muatan Lokal Bahasa Jawa

Rentang teoritik skor variabel pelaksanaan pembelajaran muatan lokal bahasa Jawa adalah 20 terendah dan 100 tertinggi. Sementara itu, berdasarkan hasil pengambilan data, statistik deskriptif data variabel pelaksanaan pembelajaran muatan lokal bahasa Jawa menunjukkan skor terendah 70 dan skor tertinggi 95. Berdasarkan hasil perhitungan, rata-rata dari variabel pelaksanaan pembelajaran muatan lokal bahasa Jawa adalah 80,6. Median terlihat pada skor 80 , sedangkan modusnya terlihat pada skor 76 dan 80 . Sementara itu, standar deviasinya adalah pada skor 6,377 .

Distribusi frekuensi data variabel pelaksanaan pembelajaran muatan lokal bahasa Jawa disajikan dalam Tabel 3 berikut ini.
Tabel 3. Distribusi Frekuensi Data

Variabel Pelaksanaan Pembelajaran

Muatan Lokal Bahasa Jawa

\begin{tabular}{|c|c|c|c|}
\hline No & $\begin{array}{c}\text { Kelas } \\
\text { Interval }\end{array}$ & $\mathrm{f}$ & $\%$ \\
\hline 1. & $70-74$ & 5 & 16,7 \\
\hline 2. & $75-79$ & 9 & 30 \\
\hline 3. & $80-84$ & 8 & 26,7 \\
\hline 4. & $85-89$ & 5 & 16,7 \\
\hline 5. & $90-94$ & 2 & 6,7 \\
\hline \multirow[t]{2}{*}{6.} & $95-99$ & 1 & 3,3 \\
\hline & umlah & 30 & 100 \\
\hline
\end{tabular}

Berdasarkan hasil pengambilan data, terdapat sejumlah 4 responden $(13,3 \%)$ yang memiliki skor 80 (rata-rata). Terdapat $46,7 \%$ responden memiliki nilai di bawah nilai rata-rata. Sedangkan $40 \%$ responden yang memiliki nilai di atas rata-rata. Angka tersebut menunjukkan $53,3 \%$ responden memiliki skor di atas skor rata-rata sampel. Dengan demikian, Tabel 3 di atas memperlihatkan data menunjukkan kurva mendekati normal dimana skor responden di atas dan di bawah skor rata-rata menunjukkan jumlah yang hampir sama. Kecenderungan data variabel pelaksanaan pembelajaran muatan lokal bahasa Jawa dapat dilihat pada gambar 1 .

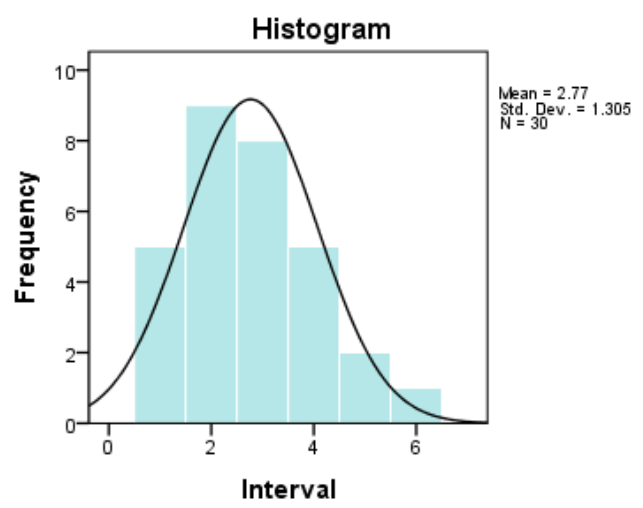

Gambar 1. Histogram Data Variabel Pelaksanaan Pembelajaran Muatan Lokal Bahasa Jawa

2. Variabel Pemahaman Wawasan atau Landasan Kependidikan

Data variabel pemahaman wawasan atau landasan kependidikan menunjukkan bahwa data tersebut mendekati kurva normal. Skor terendah data variabel pemahaman wawasan atau landasan 
kependidikan terlihat pada angka 70, sedangkan skor tertingginya terlihat pada angka 90. Rata-rata skor berada pada 78,27 dengan median 78, modus 70 dan standar deviasi 6,253. Rentang teoritik variabel pemahaman wawasan atau landasan kependidikan adalah 20 hingga 100.

Tabel 4. Distribusi Frekuensi Data Variabel Pemahaman wawasan atau Landasan Kependidikan

\begin{tabular}{|c|c|c|c|}
\hline No & $\begin{array}{l}\text { Kelas } \\
\text { Interval }\end{array}$ & $\mathrm{f}$ & $\%$ \\
\hline 1. & $70-73$ & 7 & 23,3 \\
\hline 2. & $74-77$ & 7 & 23,3 \\
\hline 3. & $78-81$ & 7 & 23,3 \\
\hline 4. & $82-85$ & 4 & 13,3 \\
\hline 5. & $86-89$ & 3 & 10 \\
\hline 6. & $90-93$ & 2 & 6,7 \\
\hline \multicolumn{2}{|r|}{ Jumlah } & 30 & 100 \\
\hline
\end{tabular}

Tabel 4 menunjukkan distribusi frekuensi data variabel pemahaman wawasan atau landasan kependidikan. Tabel tersebut menunjukkan bahwa 14 responden berada di bawah nilai rata-rata dan sejumlah 16 responden berada di atas nilai rata-rata. Data tersebut juga menunjukkan data mendekati kurva normal. Kecenderungan data variabel pemahaman wawasan atau landasan kependidikan disajikan dalam gambar 2.

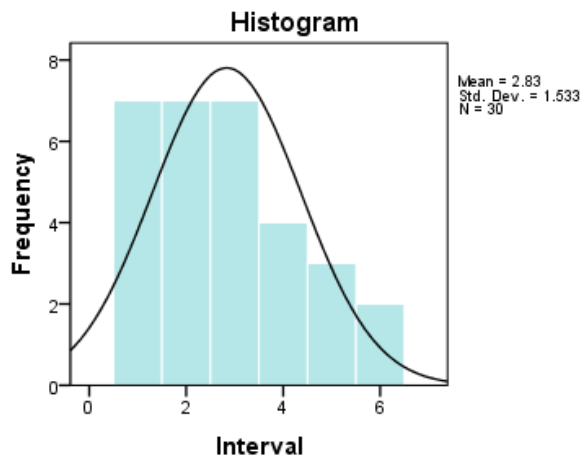

Gambar 2. Histogram Data Variabel

Pemahaman Wawasan atau Landasan Kependidikan

3. Variabel Pemahaman terhadap Peserta Didik

Data variabel pemahaman terhadap peserta didik juga memperlihatkan kurva normal. Ini juga terlihat dari tiga ukuran pemusatan yang saling berhimpitan. Skor terkecil data variabel pemahaman terhadap peserta didik adalah 64 dan data tertinggi 94. Rata-rata dari data pemahaman terhadap peserta didik adalah 76,5. Mediannya berada pada angka 76. Rata-rata dan median memperlihatkan angka yang hampir sama. Sementara itu, standar deviasinya berada pada 7,094. Sedangkan rentang teoritik variabel pemahaman terhadap peserta didik adalah 20 hingga 100.

Tabel 5. Distribusi Frekuensi Data Variabel Pemahaman wawasan atau Landasan Kependidikan

\begin{tabular}{cccc}
\hline No. & $\begin{array}{c}\text { Kelas } \\
\text { Interval }\end{array}$ & f & $\%$ \\
\hline 1. & $64-69$ & 3 & 10 \\
2. & $70-75$ & 10 & 33,3 \\
3. & $76-81$ & 10 & 33,3 \\
4. & $82-87$ & 4 & 13,3 \\
5. & $88-93$ & 2 & 6,7 \\
6. & $94-99$ & 1 & 3,3 \\
& Jumlah & 30 & 100 \\
\hline
\end{tabular}

Sumber: Hasil Penelitian (Data Diolah)

Demikian pula distribusi frekuensi data variabel pemahaman terhadap peserta didik memperlihatkan distribusi yang hampir normal. Sekitar $60 \%$ responden memiliki skor di bawah rata-rata dan $40 \%$ responden memiliki skor di atas rata-rata. Distribusi tersebut menunjukkan jumlah sampel yang berada disisi kiri dan kanan rata-rata hampir sama. Distribusi tersebut juga memperlihatkan distribusi yang hampir mendekati kurva normal. Sementara itu, kecenderungan distribusi frekuensi tersebut dapat dilihat pada Gambar 3.

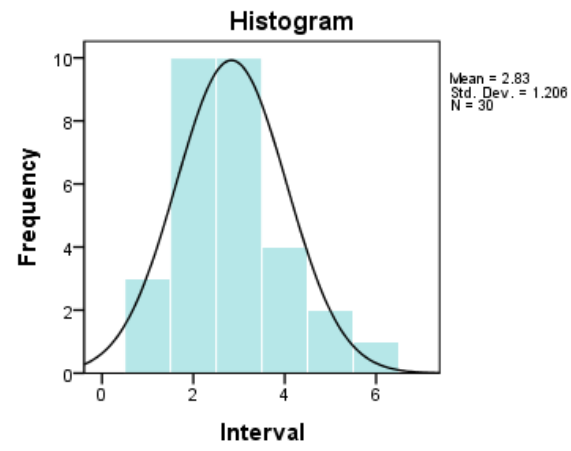

Gambar 3. Histogram Data Variabel Pemahaman terhadap Peserta Didik 
Uji validitas instrumen dilakukan terhadap 30 responden sebagai sampel penelitian. Hasil uji validitas instrumen dapat dilihat pada Tabel 6 .

Tabel 6. Hasil Uji Validitas Instrumen

\begin{tabular}{cccc}
\multicolumn{3}{c}{ Penelitian } \\
\hline Variabel & \multicolumn{2}{c}{ Hasil Validasi } & Total \\
& \multicolumn{2}{c}{ Pernyataan } & \\
\cline { 2 - 3 } & Valid & Tidak \\
Y & 13 & 7 & 20 \\
$\mathrm{X}_{1}$ & 13 & 7 & 20 \\
$\mathrm{X}_{2}$ & 13 & 7 & 20 \\
Jumlah & 39 & 21 & 60 \\
\hline
\end{tabular}

Sumber: Hasil Penelitian (Data Diolah)

Tabel 6 menunjukkan bahwa instrumen penelitian terdiri dari 60 pernyataan. Setelah dilakukan uji validasi, 39 pernyataan dinyatan valid dan 21 pernyataan dinyatakan tidak valid.

Uji reliabilitas dilakukan terhadap pernyataan-pernyataan yang valid. Hasil perhitungan reliabilitas terhadap variabelvariabel penelitian dapat dilihat pada Tabel 7.

Tabel 7. Hasil Uji Reliabilitas Setiap

\begin{tabular}{ccc} 
& Variabel \\
\hline Variabel & r hitung & r tabel \\
\hline $\mathrm{Y}$ & 0,882 & 0,6 \\
$\mathrm{X}_{1}$ & 0,691 & 0,6 \\
$\mathrm{X}_{2}$ & 0,745 & 0,6
\end{tabular}

Sumber: Hasil Penelitian (Data Diolah)

Berdasarkan perhitungan reliabilitas menggunakan bantuan software SPSS versi 20 diketahui bahwa variabel-variabel penelitian memiliki instrumen yang reliabel. Ini ditunjukkan dari nilai $r$ hitung yang lebih besar dari $r$ tabel seperti terlihat pada Tabel 7. Dengan demikian, instrumen penelitian tersebut layak untuk digunakan dalam pengambilan data.

Penelitian dilakukan menggunakan data primer yang diperoleh langsung dari sumber penelitian dimana hasil jawaban kuesioner diedarkan kepada responden penelitian (Hartana, 2013). Pengumpulan data penelitian dilakukan memalui metode survey dengan menyebarkan kuesioner kepada sejumlah sampel sebagai responden (Singarimbun dan Effendi, 1995). Pengumpulan data menggunakan metode survey dapat digunakan dalam menggambarkan fenomena baik secara deskriptif maupun inferensial. Oleh karena itu, pengumpulan data dengan metode survey sangat tepat digunakan dalam penelitian yang dilakukan ini.

Uji normalitas data hasil pengumpulan dilakukan berdasarkan kolmogorovSmirnov. Hasil perhitungan uji normalitas tersebut disajikan pada Tabel 8.

\section{Tabel 8. Hasil Uji Normalitas Variabel} Penenelitian

\begin{tabular}{ccc}
\hline Variabel & Probabilitas & Signifikansi \\
\hline $\mathrm{Y}$ & 0,622 & 0,05 \\
$\mathrm{X}_{1}$ & 0,667 & 0,05 \\
$\mathrm{X}_{2}$ & 0,612 & 0,05 \\
\hline
\end{tabular}

Sumber: Hasil Penelitian (Data Diolah)

Hasil perhitungan menunjukkan bahwa nilai probabilitas seluruh variabel penelitian menunjukkan di atas signifikansi 0,05 . Dengan demikian, dapat disimpulkan bahwa data penelitian hasil pengumpulan berdistribusi normal.

Selain dilakukan uji normalitas, data hasil penelitian juga perlu untuk dilakukan uji linieritas. Uji linieritas ini dilakukan untuk mengetahui hubungan antara variabel terikat $(\mathrm{Y})$ dengan variabel bebas $(\mathrm{X})$. Uji linieritas dilakukan menggunakan ANOVA. Hasil uji linieritas ditunjukkan pada Tabel 9.

Tabel 9. Hasil Uji Linieritas

\begin{tabular}{ccc}
\hline Variabel & Probabilitas & Signifikansi \\
\hline $\mathrm{X}_{1}$ & 0,39 & 0,05 \\
$\mathrm{X}_{2}$ & 0,259 & 0,05 \\
\hline mber: Hasil Penelitian (Data Diolah)
\end{tabular}

Pada Tabel 9 terlihat bahwa nilai probabilitas variabel penelitian lebih besar dari nilai signifikansi atau probabilitas > signifikansi. Dengan demikian, dapat disimpulkan bahwa terdapat hubungan linier antara pemahaman wawasan atau landasan kependidikan dan pemahaman 
terhadap peserta didik dengan pelaksanaan pembelajaran.

Pengujian hipotesis dilakukan terhadap ketiga hipotesis penelitian. Pengujian korelasi dilakukan untuk mengetahui besar hubungan antara variabel bebas dan variabel terikat menggunakan regresi linier sederhana. Masing-masing pengujian hipotesis tersebut terlihat sebagai berikut:

1. Pemahaman Wawasan atau Landasan

Kependidikan Berkorelasi Positif Dengan Pelaksanaan Pembelajaran Muatan Lokal Bahasa Jawa

Hasil perhitungan menunjukkan nilai probabilitas $<0,05$, maka pemahaman wawasan atau landasan kependidikan berkorelasi secara signifikan dengan pelaksanaan pembelajaran muatan lokal bahasa Jawa. Nilai korelasi hasil perhitungan adalah 0,670. Nilai tersebut menunjukkan bahwa hubungan kedua variabel penelitian kuat. Nilai koefisien determinasi yang diperoleh adalah 44,9\% sehingga variabel pemahanam wawasan atau landasan kependidikan memiliki pengaruh kontribusi sebesar $44,9 \%$ dan $55,1 \%$ lainnya dipengaruhi oleh faktor lain. Hasil perhitungan juga menunjukkan nilai Sig. <0,05, dengan demikian model persamaan regresi berdasarkan data penelitian adalah signifikan artinya model regresi linier memenuhi kriteria linieritas. Berdasarkan perhitungan menggunakan software SPSS versi 20 diperoleh persamaan regresi:

$\mathrm{Y}=27,091+0,684 \mathrm{X} 1$

\section{Korelasi Pemahaman Terhadap}

Peserta Didik dengan Pelaksanaan

Pembelajaran Muatan Lokal Bahasa Jawa.

Perhitungan menggunakan software SPSS versi 20 menunjukkan nilai probabilitas <0,05, maka pemahaman terhadap peserta didik berkorelasi secara signifikan dengan pelaksanaan pembelajaran muatan lokal bahasa Jawa. Nilai korelasi hasil perhitungan adalah 0,608 menunjukkan bahwa hubungan kedua variabel penelitian kuat. Nilai koefisien determinasi yang diperoleh adalah 36,9\% sehingga variabel pemahanam terhadap peserta didik memiliki pengaruh kontribusi sebesar $36,9 \%$ dan $63,1 \%$ lainnya dipengaruhi oleh faktor lain. Hasil perhitungan juga menunjukkan nilai Sig. $<0,05$, dengan demikian model persamaan regresi berdasarkan data penelitian adalah signifikan artinya model regresi linier memenuhi kriteria linieritas. Persamaan regresi berdasarkan perhitungan adalah sebagai berikut:

$Y=38,825+0,546 X 2$

3. Korelasi Pemahaman Wawasan atau Landasan Kependidikan dan Pemahaman terhadap Peserta Didik dengan Pelaksanaan Pembelajaran Muatan Lokal Bahasa Jawa

Nilai probabilitas hasil perhitungan menunjukkan <0,05, maka pemahaman wawasan atau landasan kependidikan dan pemahaman terhadap peserta didik berkorelasi secara signifikan dengan pelaksanaan pembelajaran muatan lokal bahasa Jawa. Nilai korelasi hasil perhitungan adalah 0,717 menunjukkan bahwa hubungan ketiga variabel penelitian kuat. Nilai koefisien determinasi yang diperoleh adalah 51,5\% sehingga variabel pemahaman wawasan atau landasan kependidikan dan pemahaman terhadap peserta didik memiliki pengaruh kontribusi sebesar $51,5 \%$ dan 48,5\% lainnya dipengaruhi oleh faktor lain. Persamaan regresi berdasarkan perhitungan adalah sebagai berikut:

$\mathrm{Y}=20,454+0,487 \mathrm{X} 1+0,288 \mathrm{X} 2$

\section{Pembahasan}

Penelitian yang dilakukan ini pada prinsipnya ingin mengetahui seberapa besar korelasi kompetensi pedagogik guru dengan pelaksanaan pembelajaran muatan lokal bahasa Jawa. Kompetensi pedagogik guru dalam penelitian ini dilihat dari dua variabel bebas, yaitu: pemahaman wawasan atau landasan kependidikan dan pemahaman terhadap peserta didik. Namun demikian, hubungan masing-masing variabel bebas dengan variabel terikat juga dicari 
secara sendiri-sendiri dalam penelitian ini. Hubungan variabel bebas dan variabel terikat dikaji secara sendiri-sendiri maupun bersama-sama berdasarkan temuan penelitian. Secara detail, pembahasan hasil penelitian diuraikan sebagai berikut:

1. Pelaksanaan Pembelajaran Muatan

\section{Lokal Bahasa Jawa}

Pelaksanaan pembelajaran muatan lokal bahasa Jawa yang dilakukan tampak sudah cukup baik. Hal ini terlihat dari perbandingan skor yang diperoleh dari responden dengan skor teoritisnya. Secara teoritis, skor terendah variabel pelaksanaan pembelajaran muatan lokal bahasa Jawa adalah 20 dan tertinggi adalah 100. Dengan membagi ke dalam 5 rentang skala, diperoleh skala seperti tampak pada Tabel 10.

Tabel 10. Rentang dan Kategori Skala Teoritis

\begin{tabular}{cl}
\hline $\begin{array}{c}\text { Rentang } \\
\text { Nilai }\end{array}$ & \multicolumn{1}{c}{ Kategori } \\
\hline $20-35$ & Sangat Kurang Baik \\
$36-51$ & Kurang Baik \\
$52-67$ & Baik \\
$68-83$ & Cukup Baik \\
$84-100$ & Sangat Baik \\
\hline
\end{tabular}

Sebagaimana diuraikan pada sub-bab di atas, skor terendah variabel pelaksanaan pembelajaran muatan lokal bahasa Jawa adalah 70 dan skor tertinggi adalah 95 . Berdasarkan Tabel 10, 20 responden $(66,7 \%)$ berada pada skala cukup baik, dan sisanya sebanyak 10 responden $(33,3 \%)$ berada pada skala sangat baik. Data tersebut menunjukkan bahwa kemampuan guru dalam melaksanakan pembelajaran muatan lokal bahasa Jawa sudah cukup baik. Jika dilihat ketiga ukuran pemusatan dara hasil penelitian, ketiganya berada pada skala cukup baik. Diketahui bahwa skor rata-rata pelaksanaan pembelajaran muatan lokal bahasa Jawa adalah 80,60, sedangkan nilai mediannya 80 , dan nilai modusnya 76 dan 80. Oleh karena itu, ketiga ukuran pemusatan data berada pada skala cukup baik. Dapat disimpulkan bahwa pelaksanaan pembelajaran muatan lokal bahasa Jawa sudah cukup baik.
2. Pemahaman Wawasan atau Landasan Kependidikan

Pemahaman wawasan atau landasan kependidikan yang dimiliki guru tampak sudah cukup baik. Hal ini terlihat dari perbandingan skor yang diperoleh dari responden dengan skor teoritisnya. Skor terendah variabel pelaksanaan pembelajaran muatan lokal bahasa Jawa adalah 20 dan tertinggi adalah 100. Dengan membagi ke dalam 5 rentang skala sebagaimana yang dilakukan dalam variabel pelaksanaan pembelajaran muatan lokal bahasa Jawa pada Tabel 10.

Diketahui pada pembahasan sub-bab sebelumnya bahwa skor terendah variabel pemahaman wawasan atau landasan kependidikan adalah 70 dan skor tertinggi adalah 90. Berdasarkan Tabel 10, 23 responden $(76,7 \%)$ berada pada skala cukup baik, dan sisanya sebanyak 7 responden $(23,3 \%)$ berada pada skala sangat baik. Data tersebut menunjukkan bahwa kemampuan guru dalam pemahaman wawasan atau landasan kependidikan sudah cukup baik. Jika dilihat ketiga ukuran pemusatan data hasil penelitian, ketiganya berada pada skala cukup baik. Diketahui bahwa skor rata-rata pelaksanaan pembelajaran muatan lokal bahasa Jawa adalah 78,27, sedangkan nilai mediannya 78 , dan nilai modusnya 70 . Oleh karena itu, ketiga ukuran pemusatan data berada pada skala cukup baik. Dapat disimpulkan bahwa pemahaman wawasan atau landasan kependidikan sudah cukup baik.

\section{Pemahaman terhadap Peserta Didik}

Perbandingan skor yang diperoleh dari responden dengan skor teoritis, terlihat bahwa pemahaman terhadap peserta didik sudah cukup baik. Skor terendah variabel pemahaman terhadap peserta didik dalam sub-bab sebelumnya diketahui adalah 64 dan skor tertingginya 94. Berdasarkan Tabel 10, 3 responden (10\%) berada pada skala baik, 23 responden $(76,7 \%)$ berada pada skala cukup baik, dan sisanya sebanyak 4 responden $(13,3 \%)$ berada pada skala sangat baik. Oleh karena itu, 
pemahaman guru terhadap peserta didik dapat dikatakan sudah cukup baik. Begitu pula hasil dari tiga pemusatan data yang menunjukkan skala yang sama. Rata-rata, median dan modus data hasil pengumpulan dari variabel pemahaman terhadap peserta didik secara berturut-turut adalah 76,5, 76 dan 72. Jika dilihat pada Tabel 10 , nilai ketiga pemusatan data berada pada skala cukup baik. Ini menunjukkan pemahaman terhadap peserta didik yang dimiliki guru sudah cukup baik.

4. Korelasi Pemahaman Wawasan atau Landasan Kependidikan dengan Pelaksanaan Pembelajaran Muatan Lokal Bahasa Jawa

Korelasi pemahaman wawasan atau landasan kependidikan dengan pelaksanaan pembelajaran muatan lokal bahasa Jawa dianalisis menggunakan regresi linier. Berdasarkan hasil perhitungan, diketahui persamaan regresi untuk variabel ini adalah $\mathrm{Y}=27,091+0,684 \mathrm{X} 1$. Nilai 0,684 merupakan bilangan konstan yang dikalikan dengan setiap nilai pada variabel pemahaman wawasan atau landasan kependidikan. Sedangkan nilai 27,091 merupakan bilangan konstan yang ditambahkan kepada setiap hasil kali bilangan konstan dengan variabel pemahaman wawasan atau landasan kependidikan. Nilai 0,684 menunjukkan bahwa garis koordinatnya sangat miring. Sebagaimana dinyatakan oleh Furqon (1999) nilai konstan yang semakin besar pada variabel $\mathrm{X}$ akan membuat garis koordinat semakin miring.

Persamaan regresi di atas menunjukkan bahwa terdapat hubungan yang positif antara variabel pemahaman wawasan atau landasan kependidikan dengan pelaksanaan pembelajaran muatan lokal bahasa Jawa. Hubungan variabel pemahaman wawasan atau landasan kependidikan dengan pelaksanaan pembelajaran muatan lokal bahasa Jawa dapat dilihat pada Gambar 5. Gambar 5 di bawah menunjukkan bahwa hubungan antara variabel pemahaman wawasan atau landasan kependidikan dengan pelaksanaan pembelajaran muatan lokal bahasa Jawa merupakan hubungan yang positif. Gambar tersebut juga menunjukkan bahwa pemahaman wawasan atau landasan kependidikan mempengaruhi pelaksanaan pembelajaran muatan lokal bahasa Jawa. Eratnya hubungan pemahaman wawasan atau landasan kependidikan dengan pelaksanaan pembelajaran muatan lokal bahasa Jawa diperkuat dengan koefisien korelasi yang signifikan pada $\alpha<0,05$.

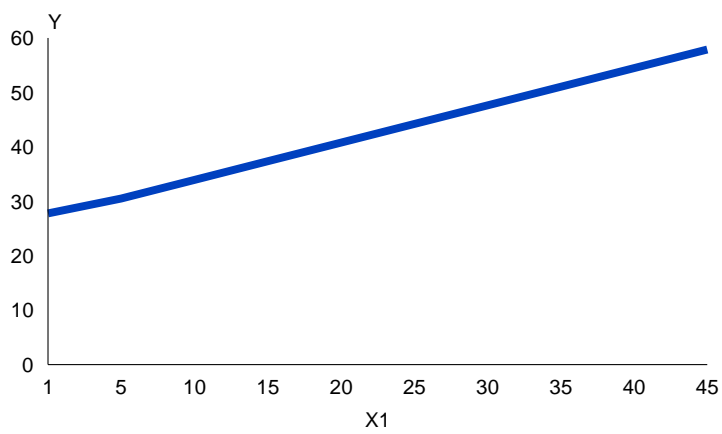

Gambar 4. Persamaan $\mathrm{Y}=27,091+$ $0,684 X_{1}$

5. Korelasi Pemahaman terhadap Peserta Didik dengan Pelaksanaan

Pembelajaran Muatan Lokal Bahasa Jawa

Berdasarkan hasil perhitungan menggunakan regresi linier, diketahui persamaan regresi untuk variabel ini adalah $\mathrm{Y}=$ $38,825+0,546 X 2$. Nilai 0,546 merupakan bilangan konstan yang dikalikan dengan setiap nilai pada variabel pemahaman terhadap peserta didik. Sedangkan nilai 38,825 merupakan bilangan konstan yang ditambahkan kepada setiap hasil kali bilangan konstan dengan variabel pemahaman terhadap peserta didik. Nilai 0,546 menunjukkan bahwa kemiringan garis koordinatnya tinggi.

Persamaan regresi di atas menunjukkan bahwa terdapat hubungan yang positif antara variabel pemahaman terhadap peserta didik dengan pelaksanaan pembelajaran muatan lokal bahasa Jawa. Hubungan kedua variabel di atas ditunjukkan oleh Gambar 6. Berdasarkan gambar tersebut, diketahui bahwa terjadi hubungan yang positif antara variabel pemahaman terhadap peserta didik dengan pelaksanaan pembelajaran muatan lokal bahasa Jawa. 
Hubungan pemahaman terhadap peserta didik dengan pelaksanaan pembelajaran muatan lokal bahasa Jawa yang erat dapat dilihat dari koefisien korelasi yang signifikan pada $\alpha<0,05$.

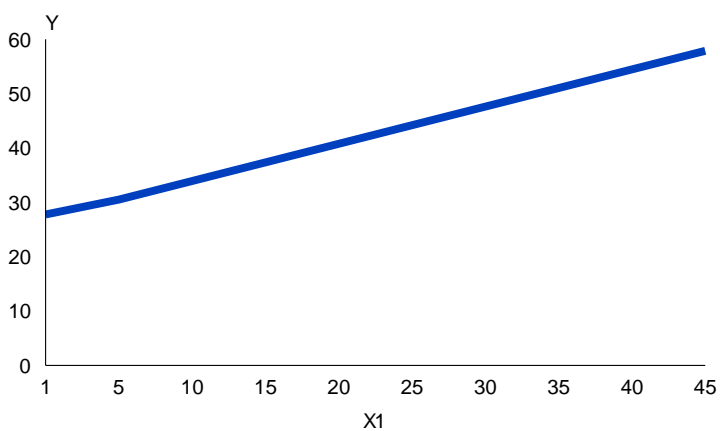

Gambar 5. Persamaan $\mathrm{Y}=38,825+$ $0,546 \mathrm{X}_{2}$

6. Korelasi Pemahaman Wawasan atau Landasan Kependidikan dan Pemahaman terhadap Peserta Didik dengan Pelaksanaan Pembelajaran Muatan Lokal Bahasa Jawa

Hubungan secara bersama-sama antara variabel pemahaman wawasan atau landasan kependidikan dengan pelaksanaan pembelajaran muatan lokal bahasa Jawa dianalisis menggunakan regresi berganda. Hubungan ketiga variabel diketahui dengan model persamaan regresi $\mathrm{Y}=20,454+$ $0,487 \mathrm{X} 1+0,288 \mathrm{X} 2$. Berdasarkan hasil analisis regresi berganda, baik pemahaman wawasan atau landasan kependidikan maupun pemahaman terhadap peserta didik berkorelasi secara signifikan dengan pelaksanaan pembelajaran muatan lokal bahasa Jawa dengan taraf signifikan $\alpha$ $<0,05$.

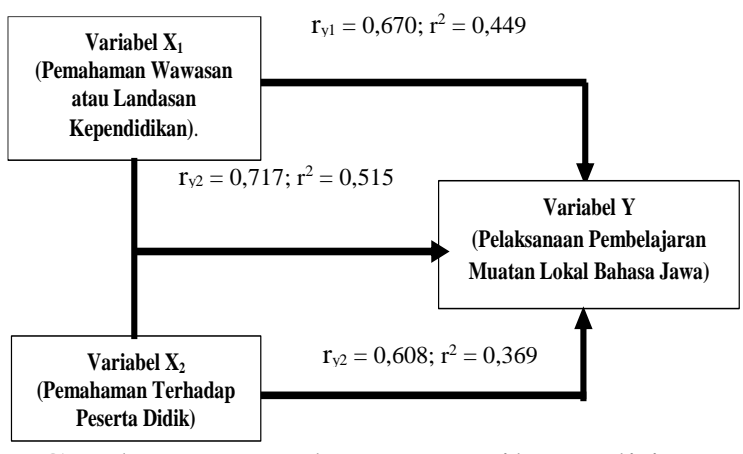

Gambar 6. Rangkuman Hasil Penelitian
Penelitian ini dilakukan dengan metode dan prosedur tertentu secara maksimal sehingga diharapkan diperoleh hasil yang baik. Meskipun demikian, dalam penelitian ini juga terjadi permasalahan diluar kontrol peneliti. Penelitian ini memiliki keterbatasan, seperti: masih sedikitnya jumlah sampel penelitian dibandingkan dengan jumlah populasi guru muatan lokal bahasa Jawa yang ada dan terbatasnya variabel bebas yang digunakan dalam penelitian ini.

\section{PENUTUP}

Hasil penelitian dan pembahasan dapat diambil kesimpulan bahwa: 1) Terdapat hubungan signifikan positif antara pemahaman wawasan atau landasan kependidikan dengan pelaksanaan pembelajaran muatan lokal bahasa Jawa dengan nilai korelasi $0,670, \mathrm{R}$ squere sebesar $44,9 \%$ dan tingkat signifikan sebesar 0,00 $<0,05$; 2) Terdapat hubungan positif antara pemahaman terhadap peserta didik dengan pelaksanaan pembelajaran muatan lokal bahasa Jawa dengan nilai korelasi 0,608, R squere sebesar $36,9 \%$ dan tingkat signifikan sebesar $0,00<0,05$; dan 3) Terdapat hubungan positif antara pemahaman wawasan atau landasan kependidikan dan pemahaman terhadap peserta didik secara bersama-sama dengan pelaksanaan pembelajaran muatan lokal bahasa Jawa dengan nilai korelasi $0,717, \mathrm{R}$ squere sebesar $51,5 \%$ dan tingkat signifikan sebesar 0,00 $<0,05$.

Dalam penelitian sejenis, peneliti memberikan beberapa saran: 1) Sampel penelitian dapat diperluas sehingga tidak terbatas pada sekolah-sekolah yang sudah menerapkan kurikulum 2013 dari kelas 7 sampai dengan kelas 9, tetapi dapat dilakukan pada seluruh sekolah yang berada di Provinsi Daerah Istimewa Yogyakarta; dan 2) Penelitian dapat menambahkan variabel lain selain variabel yang sudah ada, seperti: pengembangan kurikulum atau silabus, perencanaan pembelajaran, pemanfaatan teknologi pembelajaran, evaluasi hasil belajar, dan pengembangan peserta didik untuk 
mengaktualisasikan berbagai potensi yang dimilikinya.

\section{UCAPAN TERIMA KASIH}

Pada kesempatan ini peneliti mengucapkan terima kasih dan penghargaan setinggi-tingginya atas bimbingan, arahan, dan ijin melaqksanakan penelitian kepada yang terhormat: Dr. Laksmi Dewi, M.Pd.; Bapak dan Ibu Guru Responden penelitian.

\section{DAFTAR PUSTAKA}

Anwar. (2004). Pendidikan kecakapan hidup konsep dan aplikasi. Bandung: Alfabeta.

Arifin, M. S. (2016). Pengaruh penguasaan kompetensi pedagogik dan kompetensi profesional guru terhadap efektivitas pembelajaran Matematika pada SMA Negeri se-Kabupaten Bandung Barat. Universitas Pendidikan Indonesia.

Arikunto, S. (2014). Prosedur penelitian suatu pendekatan praktik. Jakarta: Rineka Cipta.

Bungin, B. (2011). Metodologi penelitian kuantitatif: komunikasi, ekonomi, dan kebijakan publik serta ilmu-ilmu sosial lainnya. Jakarta: Kencana Prenada Media Group.

Dantes, N. (2012). Metode penelitian. Yogyakarta: Andi.

Furqon. (1999). Statistika terapan untuk penelitian. Bandung: Alfabeta.

Hartana, B. (2013). Pengaruh kompetensi pedagogik, kompetensi profesional, dan motivasi Kerja Terhadap Kinerja Guru. Jurnal Ilmu ekonomi dan Sosial, Vol. 2, 147-162.

Irsyada, D. (2013). Pengaruh kompetensi guru dan self capacity building terhadap kinerja mengajar guru SD di kabupaten Bandung. Universitas Pendidikan Indonesia.

Maryono. (2016). The implementation of schools' policy in the development of the local content curriculum in primary schools in Pacitan, Indonesia. Academic Journal, 11(8), 891-906. https://doi.org/10.5897/ERR2016.266 0
Misbahuddin, \& Hasan, I. (2013). Analisis data penelitian dengan statistik. Jakarta: Bumi Aksara.

Mulyasa, E. (2008). Standar kompetensi dan sertifikasi guru (ketiga). Bandung: Remaja Rosdakarya.

Peraturan Pemerintah Nomor 74 Tahun 2008 tentang Guru.

Sanjaya, W. (2007). Strategi pembelajaran berorientasi standar proses pendidikan. Jakarta: Perdana Media Group.

Singarimbun, M., \& Effendi, S. (1995). Metode penelitian survei (Revisi). Jakarta: Pustaka LP3ES.

Siscahyani. (2011). Manajemen kurikulum muatan lokal bahasa Jawa di sekolah menengah pertama negeri sekecamatan Depok Sleman Yogyakarta. Yogyakarta.

Suci, U. A. (2015). Pengaruh motivasi kerja dan implementasi kurikulum 2013 melalui kegiatan pendampingan terhadap kinerja guru di SMA negeri 2 Kandangan. Jurnal Ilmiah Ekonomi Bisnis, Vol. 1, 399-411.

Sudjana, N., \& Ibrahim. (2014). Penelitian dan penilaian pendidikan. Bandung: Sinar Baru Algensindo.

Sudjarwadi. (2006). Strategi pembelajaran bahasa Jawa bagi anak-anak. In Kongres Bahasa Jawa IV. Semarang.

Sukardi. (2011). Metodologi penelitian pendidikan. Jakarta: Bumi Aksara.

Suwardi. (2005). Metode pembelajaran bahasa Jawa. Yogyakarta: Departemen Agama Propinsi DIY. Diambil dari http://staff.uny.ac.id/sites/default/files /pengabdian/dr-suwardimhum/c2metode.pdf

Undang-Undang Republik Indonesia Nomor 14 Tahun 2005 tentang Guru dan Dosen.

Uno, H. B. (2007). Teori motivasi dan pengukurannya analisis di bidang pendidikan. Jakarta: Bumi Aksara.

Usman, H., \& Akbar, R. P. S. (1995). Pengantar statistika. Jakarta: Bumi Aksara. 
Usman, M. U. (2011). Menjadi guru profesional. Bandung: Remaja Rosdakarya.

Wahyuni, N. S. (2014). Implementasi muatan lokal membatik di SMA negeri I Situbondo. Jurnal Pendidikan Humaniora (JPH), 1(4), 337-342. https://doi.org/10.17977/JPH.V1I4.41 43

Wurm, S. A. (2001). Atlas of the world's language in danger of disappearing. Paris: UNESCO Publishing. 